\title{
Tectonic setting and exhumation history of the Pingtan-Dongshan Metamorphic Belt along the coastal area, Fujian Province, Southeast China
}

\author{
Wen-Shan Chen ${ }^{\mathrm{a}, *}$, Hsiao-Chin Yang ${ }^{\mathrm{a}}$, Xin Wang ${ }^{\mathrm{b}}$, Hui Huang ${ }^{\mathrm{c}}$ \\ ${ }^{a}$ National Taiwan University, 245 Choushan Road, Taipei 106, Taiwan, ROC \\ ${ }^{\mathrm{b}}$ Department of Geology, Zhejiang University, Zhejiang, People's Republic of China \\ ${ }^{\mathrm{c}}$ Geosciences Institute of Fujian Province, Fuzhou, People's Republic of China
}

Received 6 June 2000; revised 3 April 2001; accepted 11 July 2001

\begin{abstract}
In the coastal region of the Fujian Province, the semi-ductile Changle-Nanao shear zone is spatially associated with the PingtanDongshan Metamorphic Belt and a Late Cretaceous Magmatic Belt. The Metamorphic Belt was thrust onto the rocks of the Magmatic Belt along the Changle-Nanao shear zone. Uplifting of the Metamorphic Belt may have resulted in oblique underplating of an ancient Pacific plate, forming a left-lateral reverse strike-slip or transcurrent fault at the rear of a forearc basin. Based on ${ }^{40} \mathrm{Ar} /{ }^{39} \mathrm{Ar}$ ages, it is shown that this Metamorphic Belt was active from 132 to $82 \mathrm{Ma}$. The timing of exhumation varied spatially from north to south and appears to become younger in a southward direction. In the northern part of the Metamorphic Belt, the metamorphic rocks cooled rapidly at a rate of about $47^{\circ} \mathrm{C} /$ m.y. from 132 to $126 \mathrm{Ma}$, but the cooling rate decreased to $13-20^{\circ} \mathrm{C} / \mathrm{m}$.y. during the period $126-110 \mathrm{Ma}$. As constrained by the plateau dates of the overlying volcanic rocks $(\sim 110 \mathrm{Ma})$, the rocks now at the surface had reached at the surface by $\sim 110$ Ma. No conspicuous exhumation had occurred since then. In contrast, the exposed rocks from the middle and southern part of the Metamorphic Belt started cooling much later, dropping to $550^{\circ} \mathrm{C}$ by $\sim 110 \mathrm{Ma}$. They appear to have cooled at an average rate of $40-50^{\circ} \mathrm{C} / \mathrm{m}$.y. from $550-300^{\circ} \mathrm{C}$, followed by slower cooling at circa $15-30^{\circ} \mathrm{C} / \mathrm{m}$.y. to $300-150^{\circ} \mathrm{C}$. (C) 2002 Elsevier Science Ltd. All rights reserved.
\end{abstract}

Keywords: Pingtan-Dongshan Metamorphic Belt; Changle-Nanao shear zone; ${ }^{40} \mathrm{Ar}-{ }^{39} \mathrm{Ar}$ thermochronology

\section{Introduction}

The Pingtan-Dongshan Metamorphic Belt is composed of metamorphic pre-Mesozoic rocks, which are intruded by Late Mesozoic granites and mafic dikes, and juxtaposed with a Late Mesozoic Magmatic Belt along the ChangleNanao shear zone (Fig. 1). Within the past decade, geologists have conjectured that the Metamorphic Belt formed a suture zone or orogenic belt related to continental collision during the Jurassic-Cretaceous periods (Hsu et al., 1990; Gao et al., 1991; Li, 1993; Huang et al., 1993; Lu et al., 1994). Some have inferred that westward subduction of a Gunanhai ocean underplated the Huanan continent had resulted in volcanism during the Late Mesozoic ( $\mathrm{Li}, 1993$; Lu et al., 1994). Hsu et al. (1990), however, postulated that the Gunanhai ocean plate was consumed by eastward

\footnotetext{
* Corresponding author. Tel.: +886-2-2369-6594; fax: +886-2-23636095.

E-mail address: wenshan@ms.cc.ntu.edu.tw (W.-S. Chen).
}

subduction beneath the Dongnanya block during the Permian to Jurassic periods. However, it is generally believed that the margin of SE China was an Andean type continental margin during the Mesozoic due to the westward subduction of the Kula/Izanagi plate (Uyeda and Miyashiro, 1974; Jahn et al., 1976; Engebreton et al., 1985; Faure, 1989; Filatova, 1996; Lapierre et al., 1997). These different opinions are mainly based on the interpretation of the exposed gabbro and amphibolite in this metamorphic belt and on whether or not these rocks represent an ophiolite. Recently, some authors have proposed that the Cretaceous magmatism in SE China was generated in response to lithospheric extension (Lo et al., 1996; Li, 2000).

The thermochronological study of a metamorphic complex can potentially provide significant information regarding the tectonic processes operative within that complex. Age differences between the coexisting minerals provide an average cooling rate between the respective closure temperatures. Hence, with a combination of closure temperature estimates and age dating, the cooling path of a 


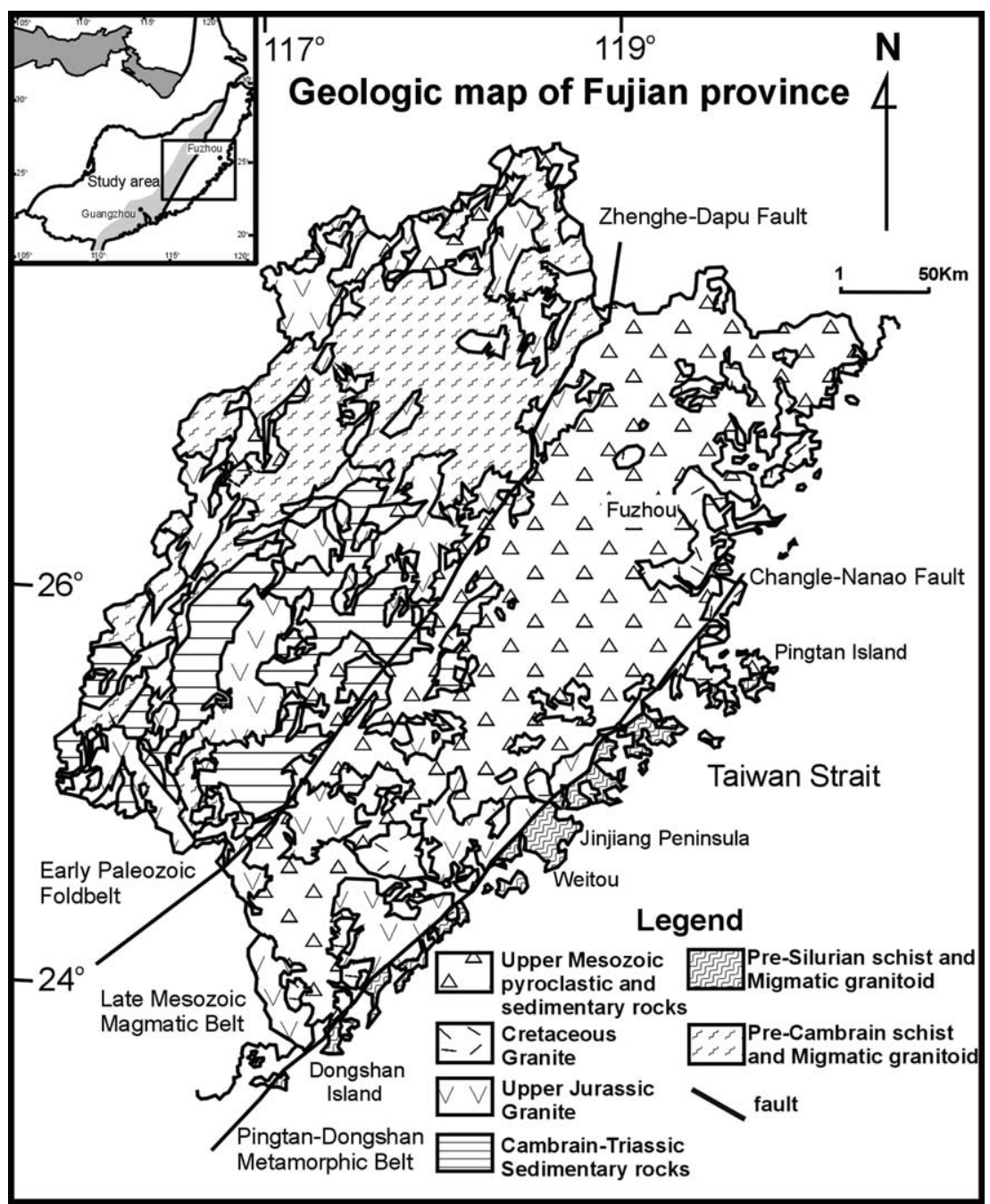

Fig. 1. Geological map of the Fujian Province modified from Fujian (1985). The Changle-Nanao and Zhenghe-Dapu Faults divide the Fujian Province into three tectonic belts which are the Caledonian Foldbelt, the Yanshanian Magmatic Belt and the Pingtan-Dongshan Metamorphic Belt from west to east.

given area over temperatures ranging from 150 to $550^{\circ} \mathrm{C}$ can generally be derived from the ${ }^{40} \mathrm{Ar} /{ }^{39} \mathrm{Ar}$ thermochronological data (McDougall and Harrison, 1988). The present work focuses on thermochronological studies of the cooling histories of metamorphic rocks along the Metamorphic Belt and evaluation its tectonic setting.

\section{Regional geology}

The Changle-Nanao shear zone is the most important NE trending fault in the eastern Fujian province, which is divided from west to east into: (1) a Cretaceous Magmatic Belt, and (2) the Pingtan-Dongshan Metamorphic Belt (Fig. 1).

\subsection{The Cretaceous Magmatic Belt}

The Cretaceous Magmatic Belt between the ZhengheDapu and Changle-Nanao shear zones exposes Cretaceous granitic and volcanic rocks (Fig. 2). The magmatic belt overlies a pre-Cretaceous sedimentary sequence and preDevonian metamorphic rocks. The granite is mainly of I-type (Fujian, 1985) and is mostly exposed along the southern part of the belt. The volcanic rocks are concentrated in the northern area and are up to $2000 \mathrm{~m}$ thick with interbedded lava, pyroclastic and subaerial epiclastic deposits. In the belt extending from Guangdong to Zhejiang Provinces, there is more granite exposed southward and more volcanic rocks towards the north. Much of the stratigraphic record may have been eroded in the southern part of the Magmatic Belt. We suggest that differential exhumation may have occurred during the Cenozoic. The magmatic belt exhibited characteristics of an Andean-type magmatic arc during the late Mesozoic (Uyeda and Miyashiro, 1974; Jahn et al., 1976; Faure, 1989; Lapierre et al., 1997), although a magmatic belt more than $1000 \mathrm{~km}$ in width is far greater than that normally observed in subduction zones. The late Cretaceous igneous rocks include A-type granite, ignimbrite and basaltic lava, which indicate bimodal volcanism (Martin et al., 1994; Zhou and Wu, 1994; Lee, 1994), and 


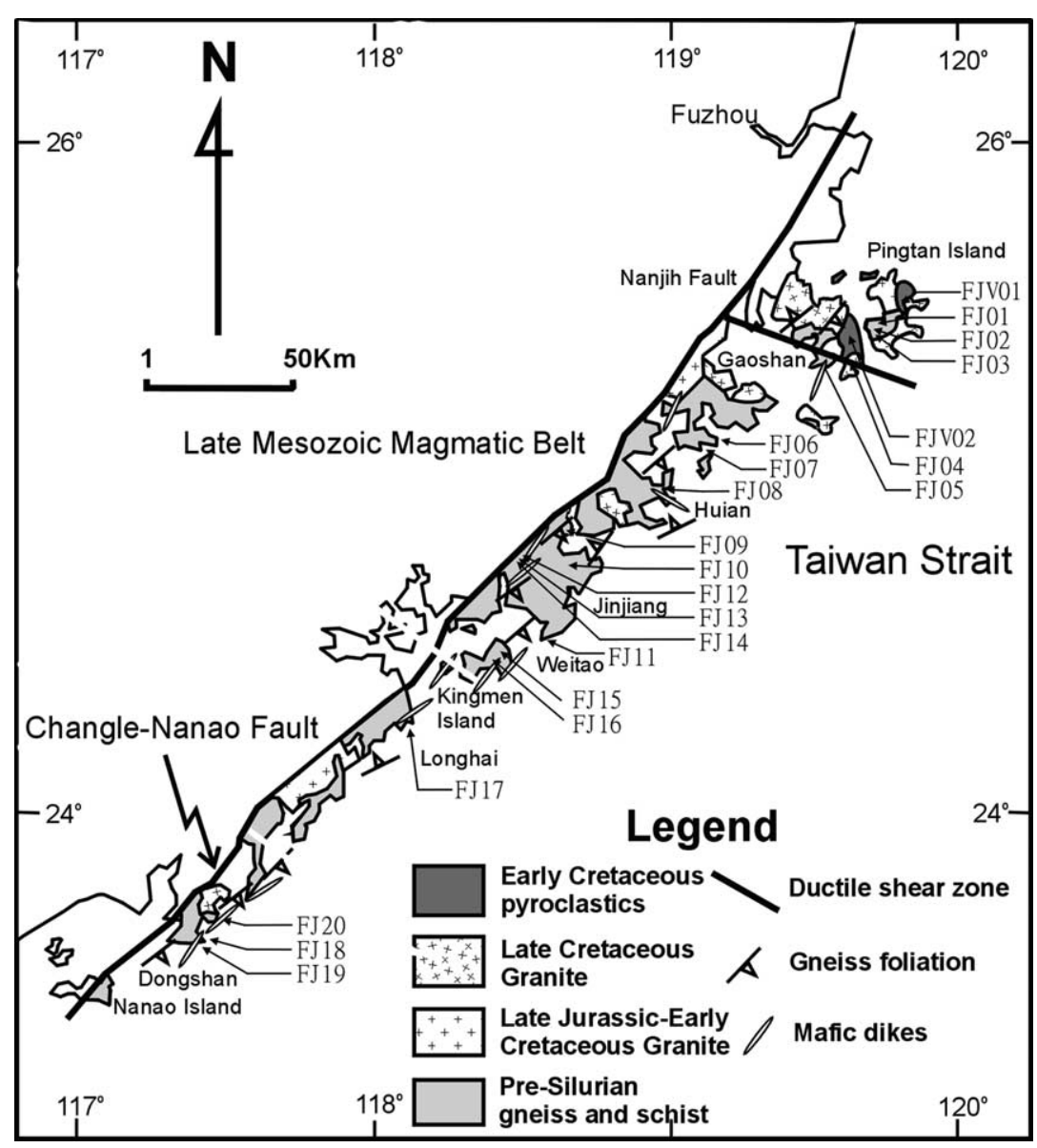

Fig. 2. A simplified geological map of the Pingtan-Dongshan Metamorphic Belt and Changle-Nanao shear zone. The locations of samples analyzed for this study and the trend of gneissosity are also shown.

therefore seem to represent an extensional environment during the late Cretaceous (Lee, 1994; Li, 2000).

\subsection{The Pingtan-Dongshan Metamorphic Belt}

The Metamorphic Belt exposed in the coastal region of Fujian Province is mainly composed of migmatitic gneiss with some pelitic schist intruded by Late Mesozoic granitic plutons, and mafic dikes. Scattered late Cretaceous volcanic rocks overlie in the northern part of the Metamorphic Belt (Fig. 2). The plutonic rocks consist of Early Cretaceous Itype granites and minor Late Cretaceous A-type granites, which are commonly explained as subduction-related and intraplate extension-related granites, respectively (Chen et al., 2000). Late Cretaceous mafic dikes occur widely and the geochemical characteristics suggest an extensional environment (Lee, 1994). Theoretically, the trends of dikes are commonly perpendicular to the orientation of the least principal stress (Suppe, 1985; Emerman and Marrett, 1990). According to our measurement, these mafic dykes are oriented $30-50^{\circ} \mathrm{NE}$ and range from steeply dipping to vertical and the least principal stress analysis indicate a NW-SE extensional direction during the late Cretaceous to Eocene.

The migmatitic gneiss suite is composed of stromatic, schlieren, nebulitic, augen and leptite structures containing abundant pervasive foliation. Mylonitic structure is commonly observed in outcrop and is characterized by pervasive, closely spaced, relatively straight fractures which are roughly parallel to the trend of the ChangleNanao shear zone. The mylonitic structure may therefore be related to movements along the Changle-Nanao shear zone.

The gneiss frequently exhibits a well-developed stromatic structure, in the form of alternating leucosome and mesosome layers due to the preferred orientation of biotite. Our analysis of the regional strike of gneissosity in this belt dominantly shows a $30-50^{\circ} \mathrm{NE}$ trend with dips to the southeast or northwest. The orientation of gneissosity in the most obvious outcrops appears not to have been affected by emplacement of the granitic plutons. The Cretaceous granite and the mafic dikes commonly cut through the gneissosity that is usually oblique or perpendicular to the intrusive contacts. In some areas, the granite contains xenoliths of migmatitic gneiss and pelitic schist. It appears that the high-grade metamorphism occurred before the emplacement of the late Mesozoic granite. It is also suggested that the gneissosity has no relation to granite emplacement (Yang et al., 1997). 


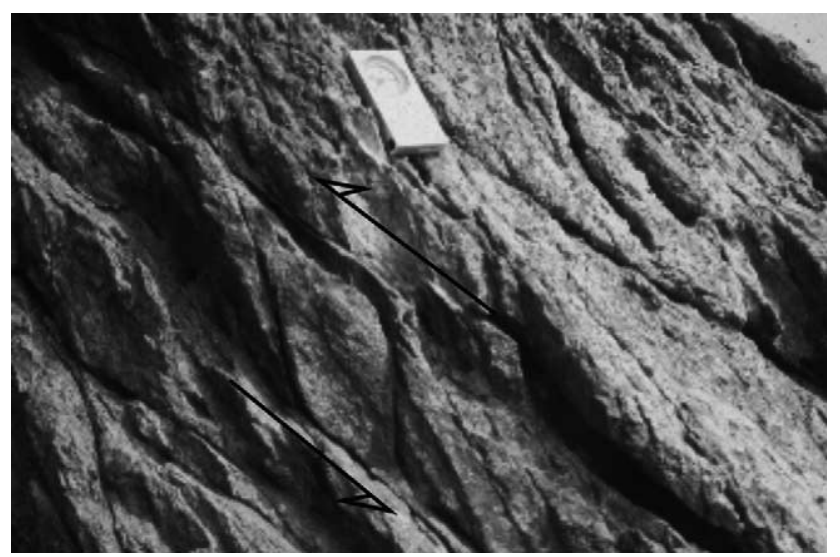

Fig. 3. S-C fabrics developing in the sheared Cretaceous volcanic rocks along the Changle-Nanao shear zone show a sinistral sense of shear.

\subsection{The Changle-Nanao shear zone}

This fault is characterized by brittle to ductile shearing that distinguishes it from the Magmatic and Pingtan-Dongshan Metamorphic Belts. This northeast trending major tectonic feature extends nearly $400 \mathrm{~km}$ along the coastal region of Fujian Province. The metamorphic rocks within this ductile shear zone mainly consist of phyllites representing Jurassic volcanic rocks. The mineral assemblage of the phyllites indicates lower greenschist-facies metamorphism that occurred at a temperature of about $300-350^{\circ} \mathrm{C}$ (Huang et al., 1993; Tong and Tobisch, 1996). The shear zone shows well-defined mineral alignment and stretching lineations of quartz that lie along the foliated plane. Our analysis of the trend of schistosity within the early Cretaceous volcanic rocks is dominantly $30-50^{\circ} \mathrm{NE}$ and steeply dipping to the east or southeast (Wang et al., 1995). The sheared volcanic rocks show a $\mathrm{S}-\mathrm{C}$ fabric with a left-lateral component indicating a southeast over northwest sense of movement (Fig. 3 ). The mineral lineations in the foliation plane exhibit a preferred orientation plunging to the SE and are associated with a NW-directed sense of movement of the hangingwall block (relative to present-day geographical co-ordinates). This indicates that the Pingtan-Dongshan Metamorphic Belt was thrust onto the Cretaceous Magmatic Belt. Although, the shear zone was mainly developed during ductile deformation, it is also locally characterized by brittle deformation. The early Cretaceous volcanics were buried along the Changle-Nanao shear zone which cuts through the volcanics in a brittle manner. The late Cretaceous mafic dikes cut through the shear zone and were unaffected by ductile deformation. Based on this field relationship, we suggest that the Changle-Nanao shear zone was active and exposed at the surface during the Late Cretaceous.

\section{Analytical methods}

After being ultrasonically cleaned in acetone and distilled water, the 20-80 sieve-sized fractions of the mineral separates were chosen for mineral separation. Pure mineral concentrates were obtained by using a magnetic separating technique followed by paper shaking, heavy liquid treatment and finally hand-picking to remove all visible impurities. The mineral concentrates were then wrapped into disk-shaped Al-foil packets, stacked in an Al-canister and irradiated at VT-C position in the THOR reactor located at Tsing-Hua University (Hsinchu, Taiwan). Neutron flux gradients were monitored with MMhb-1 hornblende standard with a $\mathrm{K}$-Ar age of $520.4 \pm 1.7 \mathrm{Ma}$ (Samson and Alexander, 1987) and LP-6 biotite standard with a K-Ar age of $127.7 \pm 1.4 \mathrm{Ma}$ (Odin et al., 1982). After irradiation, the samples were incrementally degassed in steps ranging from $\sim 450$ to $1200^{\circ} \mathrm{C}$ using a 30-minute/step heating schedule. The purified gas was then analyzed using VG3600 and GD150 mass spectrometers at National Taiwan University. The detail analytical and correction techniques have been discussed by Lo and Lee (1994) for the THOR reactor. The plateau date was calculated as the inverse variance weighted mean of dates from steps on the plateau. The criteria used to define a plateau included $50 \%$ or more of the total ${ }^{39} \mathrm{Ar}$ released in three or more consecutive steps with apparent dates agreeing within $2 \sigma$.

\section{Thermochronologic results}

Thirty-eight samples were analyzed by the conventional ${ }^{40} \mathrm{Ar} /{ }^{39} \mathrm{Ar}$ step-heating method. A summary of the results of the ${ }^{40} \mathrm{Ar} /{ }^{39} \mathrm{Ar}$ step-heating is listed in Table 1 and they are also presented as age spectra in Fig. 4.

\subsection{The Pingtan-Dongshan Metamorphic Belt}

The metamorphic belt is composed mainly of migmatitic gneiss containing minor melanocratic enclaves of hornblende and biotite laminae. We took great care in extracting minerals from the melanocratic enclave and migmatitic gneiss and selected hornblende, muscovite, biotite and $\mathrm{K}$ feldspar for ${ }^{40} \mathrm{Ar} /{ }^{39} \mathrm{Ar}$ dating (Table 1, Fig. 4). On the basis of the ${ }^{40} \mathrm{Ar} /{ }^{39} \mathrm{Ar}$ dates of the analyzed minerals and the obtained closure temperatures, the time-temperature diagram for the samples were constructed as shown in Fig. 5. On the basis of age differences among the spatial distributions, we divided the metamorphic belt into three parts from the north to south as follows.

Six minerals were analyzed from four rocks collected from the northern part of the Metamorphic Belt (Pingtan area, Fig. 2). Hornblende separates from the FJ01 migmatitic gneiss display a discordant age spectrum, with ${ }^{40} \mathrm{Ar} /{ }^{39} \mathrm{Ar}$ apparent dates decreasing initially from the first step ( $\sim 168 \mathrm{Ma})$ to a flat region over the mid-temperature range $(\sim 132 \mathrm{Ma})$. They then gradually increase at higher temperatures, and finally decrease again in the last step (97 Ma) (Fig. 4). Such a 'saddle-shaped' age spectrum is similar to those documented for minerals with excess argon 
Table 1

Summary of ${ }^{40} \mathrm{Ar} /{ }^{39} \mathrm{Ar}$ results in the Pingtan-Dongshan Metamorphic Belt

\begin{tabular}{|c|c|c|c|c|c|}
\hline Sample & Locality & Rock type & Mineral/rock & Date (Ma) & Calculated $T_{\mathrm{c}}\left({ }^{\circ} \mathrm{C}\right)$ \\
\hline FJ01 & Pingtan & Gneiss & Hornblende & $132.8 \pm 3.3$ & $540 \pm 20$ \\
\hline \multirow[t]{2}{*}{$\mathrm{FJ} 02$} & Pingtan & Gneiss & Biotite & $126.5 \pm 2.4$ & $333 \pm 2$ \\
\hline & & & K-feldspar & $116.3 \pm 2.4$ & $131 \pm 89$ \\
\hline \multirow[t]{2}{*}{ FJ03 } & Pingtan & Gneiss & Biotite & $126.5 \pm 3.1$ & $329 \pm 2$ \\
\hline & & & K-feldspar & $111.6 \pm 2.7$ & $140 \pm 30$ \\
\hline FJ04 & Lianhuashan & Gabbro & Hornblende & $131.2 \pm 0.6$ & $\sim 550$ \\
\hline FJV01 & Pingtan & Basalt & Whole rock & $109.9 \pm 2.3$ & \\
\hline FJV02 & Gaoshan & Rhyolite & Whole rock & $110.1 \pm 2.3$ & \\
\hline \multirow[t]{3}{*}{ FJ05 } & Gaoshan & Gneiss & Hornblende & $109.6 \pm 2.6$ & $542 \pm 4$ \\
\hline & & & Biotite & $105.3 \pm 2.1$ & $346 \pm 2$ \\
\hline & & & K-feldspar & $100.7 \pm 2.1$ & $223 \pm 72$ \\
\hline FJ06 & Putien & Schist & Muscovite & $98.8 \pm 2.4$ & $\sim 400$ \\
\hline \multirow[t]{3}{*}{ FJ07 } & Putien & Gneiss & Hornblende & $108.6 \pm 2.7$ & $537 \pm 13$ \\
\hline & & & Biotite & $106.7 \pm 2.6$ & $350 \pm 5$ \\
\hline & & & K-feldspar & $94.5 \pm 2.3$ & $139 \pm 49$ \\
\hline \multirow[t]{3}{*}{ FJ08 } & Huian & Gneiss & Hornblende & $102.4 \pm 2.5$ & $566 \pm 7$ \\
\hline & & & Biotite & $101.4 \pm 2.5$ & $341 \pm 5$ \\
\hline & & & K-feldspar & $98.4 \pm 2.4$ & $242 \pm 58$ \\
\hline \multirow[t]{2}{*}{ FJ09 } & Houtsu & Gneiss & Biotite & $99.9 \pm 1.5$ & $339 \pm 11$ \\
\hline & & & K-feldspar & $89.5 \pm 1.4$ & $232 \pm 17$ \\
\hline \multirow[t]{2}{*}{ FJ10 } & Linghsiushan & Gneiss & Biotite & $94.2 \pm 2.0$ & $336 \pm 11$ \\
\hline & & & K-feldspar & $86.0 \pm 0.8$ & $221 \pm 11$ \\
\hline \multirow[t]{2}{*}{ FJ11 } & Weitao & Gneiss & Biotite & $90.2 \pm 1.5$ & $325 \pm 11$ \\
\hline & & & K-feldspar & $87.2 \pm 1.4$ & $251 \pm 5$ \\
\hline \multirow[t]{2}{*}{ FJ12 } & Shihtaoshan & Mylonite & Hornblende & $102.8 \pm 2.2$ & $504 \pm 20$ \\
\hline & & & K-feldspar & $88.0 \pm 1.8$ & $106 \pm 40$ \\
\hline \multirow[t]{2}{*}{ FJ13 } & Shihtaoshan & Gneiss & Biotite & $101.8 \pm 2.3$ & $331 \pm 11$ \\
\hline & & & K-feldspar & $87.0 \pm 1.8$ & $149 \pm 30$ \\
\hline FJ14 & Shihtaoshan & Mafic dyke & Whole rock & $82.2 \pm 1.7$ & \\
\hline FJ15 & Kingmen & Mafic dyke & Hornblende & $97.1 \pm 1.6$ & $\sim 550$ \\
\hline FJ16 & Kingmen & Gneiss & Biotite & $89.9 \pm 1.5$ & $331 \pm 11$ \\
\hline \multirow[t]{2}{*}{ FJ17 } & Shenao & Gneiss & Hornblende & $91.6 \pm 1.9$ & $\sim 550$ \\
\hline & & & K-feldspar & $86.9 \pm 1.8$ & $331 \pm 11$ \\
\hline FJ18 & Dongshan & Schist & Muscovite & $91.9 \pm 2.3$ & $\sim 400$ \\
\hline \multirow[t]{2}{*}{ FJ19 } & Dongshan & Gneiss & Biotite & $87.7 \pm 1.8$ & $326 \pm 5$ \\
\hline & & & K-feldspar & $83.7 \pm 1.7$ & $156 \pm 13$ \\
\hline \multirow[t]{2}{*}{$\mathrm{FJ} 20$} & Dongshan & Gneiss & Muscovite & $93.7 \pm 1.9$ & $\sim 400$ \\
\hline & & & biotite & $88.4 \pm 1.8$ & $\sim 300$ \\
\hline
\end{tabular}

for samples with a mixing of mineral phases (e.g. Cosca and O'Nions, 1994; Lo and Yui, 1996). The gas fractions released during the moderate temperature step yield an approximately flat profile in the age spectrum with an apparent date around $132.8 \pm 3.3 \mathrm{Ma}$. The biotite separates from the migmatitic gneiss (FJ02) and biotite granite (FJ03) in the Pingtan region display fairly flat age spectra over most parts of the total ${ }^{39} \mathrm{Ar}$ released (Fig. 4). As shown, the mid-temperature steps in sample FJ02 form a plateau with an age of $126.5 \pm 2.6 \mathrm{Ma}$, whereas those in FJ03 biotite yield a plateau date of around $126.5 \pm 3.1 \mathrm{Ma}$. Similarly, two K-feldspars from the migmatitic gneiss (FJ02) and biotite granite (FJ03) also show flat age spectra over the range $>96 \%$ of the total ${ }^{39} \mathrm{Ar}$ released with plateau dates of $116.3 \pm 2.4$ and $111.6 \pm 2.7 \mathrm{Ma}$, respectively. As discussed by many previous researchers, a flat profile in the K-feldspar age spectrum is characteristic of a relatively fast cooling terrane (Lovera et al., 1989; Lo et al., 1993). If this were the case, then the flat age spectra of the FJ02 and
FJ03 K-feldspars would suggest fast cooling periods during which the rocks cooled through the closure temperature range of K-feldspar $\left(\sim 300-150^{\circ} \mathrm{C}\right)$ at around 116$111 \mathrm{Ma}$. Hornblende from sample FJ04 yields an age spectrum that, in general, rises monotonically from 121.1 to $153.7 \mathrm{Ma}$ (Fig. 4) and the integration of the gas compositions for all steps indicates an age of $131.2 \pm 0.6 \mathrm{Ma}$ (Table 1, Fig. 4).

Two types of volcanic rocks, including basalt and rhyolite, are widely distributed in the northern part of the Metamorphic Belt. Sample FJV01 was taken from a $50 \mathrm{~m}$ thick basalt flow from Pingtan Island. Its gas fractions also define a plateau on the age spectrum with the plateau date of $109.9 \pm 2.3 \mathrm{Ma}$. Rhyolite appears dominantly in the Shihmaoshan Group, which is interlayered with basaltic volcanic units. Sample FJV02 is from a rhyolite overlying migmatitic gneiss and yields a plateau on the age spectrum, comprising $>85 \%$ of the total ${ }^{39} \mathrm{Ar}$ released, with an age of $110.1 \pm$ 2.3 Ma based on ${ }^{40} \mathrm{Ar} /{ }^{39} \mathrm{Ar}$ analysis. 

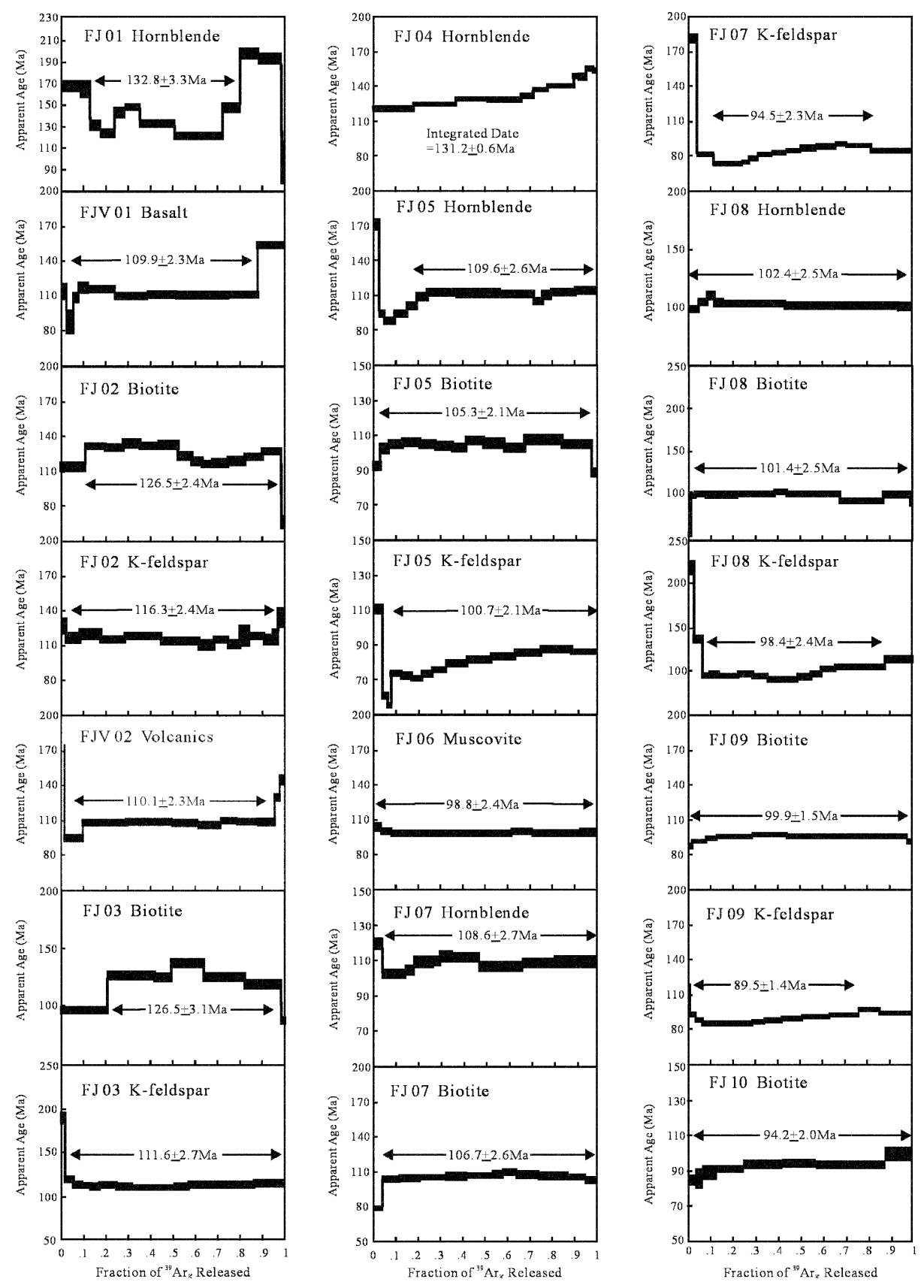

Fig. $4 .{ }^{40} \mathrm{Ar} /{ }^{39} \mathrm{Ar}$ age spectra for the mineral separates analyzed.

Analysis within the middle portion of the belt between Gaoshan and Kingmen Island, indicates a general southward younging trend as demonstrated by hornblende, biotite and K-feldspar ages.

Hornblende from sample FJ05 yields an age spectrum with somewhat discordant apparent dates at the low-temperature steps. However, the high temperature steps still yield a well defined plateau, with an age of $109.6 \pm 2.6 \mathrm{Ma}$ over $80 \%$ of the total ${ }^{39} \mathrm{Ar}$ released. In contrast to the hornblende separates, except for some discordant ones at the lowest and highest heating steps, the biotite separates from sample FJ05 display concordant apparent dates over most of the ${ }^{39} \mathrm{Ar}$ released $(>95 \%)$ and exhibit a plateau date of $105.3 \pm$ 2.1 Ma (Fig. 4). As shown in Fig. 4, K-feldspar from the FJ05 migmatitic gneiss displays a staircase-shaped age spectrum with some anomalously old ages in the first three steps. Nevertheless, the gas fractions released from most of the temperature steps (comprising $>65 \%$ of the total ${ }^{39} \mathrm{Ar}$ released) still define a plateau with an age of $100.7 \pm 2.1 \mathrm{Ma}$.

Sample FJ06 is a sillimanite-muscovite schist superimposed on migmatitic gneisses. A muscovite separate from the schist (FJ06) yields a flat spectrum with a plateau date of $98.8 \pm 2.4$ Ma (Table 1, Fig. 4). Sample FJ07, collected from the maritime of the Putian region, is a coarse-grained 

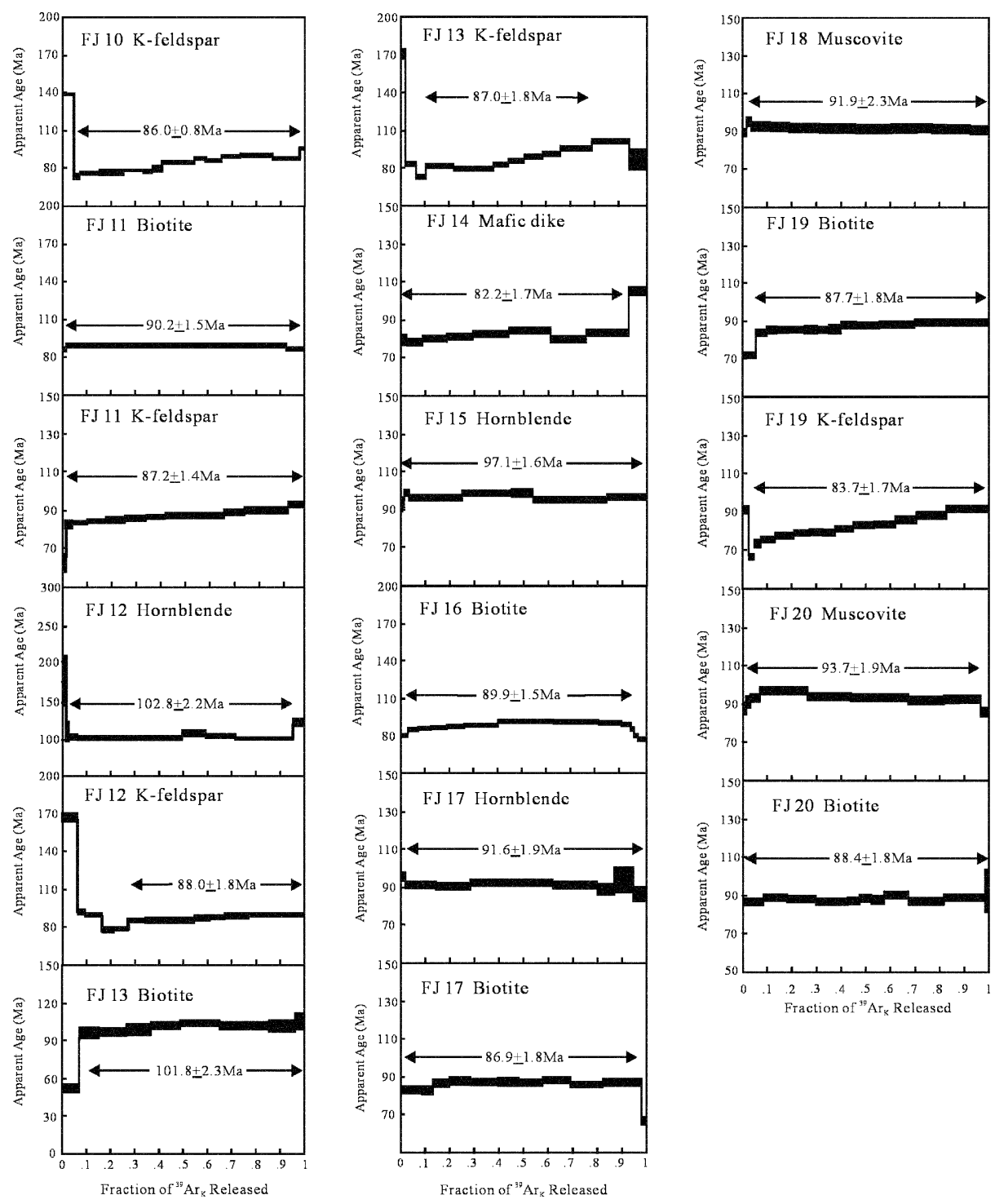

Fig. 4. (continued)

migmatitic gneiss. Hornblende from this sample yields a flat age spectrum over $95 \%$ of ${ }^{39} \mathrm{Ar}$ released, with a plateau date of 108.6 $\pm 2.7 \mathrm{Ma}$. Similar to hornblende, biotite from the sample also displays a flat spectrum with an age of $106.7 \pm$ 2.6 Ma. The lowest and highest temperature steps appear to have somewhat younger ages, which may have been due to the outgasing of some impurities. K-feldspar from sample FJ07 displays a staircase-shaped spectrum with their apparent dates increasing monotonously with increasing temperatures, except for those with an anomalously old age at the first step. Nevertheless, most of the apparent ages are still concordant within $2 \sigma$, and exhibit a meaningful plateau with an age of $94.5 \pm 2.4 \mathrm{Ma}$ (Table 1, Fig. 4).

Sample FJ08 is a migmatitic gneiss collected from the Longkushan quarry in the Huian region. Hornblende and biotite separates from sample FJ08 both display relatively flat plateau spectra except at the lowest temperature step with a plateau date of $102.4 \pm 2.5$ and $101.4 \pm 2.5 \mathrm{Ma}$, respectively. Other than at the first two and the highesttemperature steps, the age spectrum of K-feldspar from sample FJ08 displays a relatively flat profile over $85 \%$ of total ${ }^{39} \mathrm{Ar}$ released (Fig. 4) with an age of $98.4 \pm 2.4 \mathrm{Ma}$.

Biotite and K-feldspar were extracted from three migmatitic gneisses from the Houch (FJ09), Linghsiushan (FJ10) and Weitou (FJ11) regions in the Jinjiang Peninsula. All the biotites extracted from these migmatitic gneisses display internally concordant age spectra with well-defined plateau dates as $99.9 \pm 1.5 \mathrm{Ma}$ for FJ09, 94.2 $\pm 2.0 \mathrm{Ma}$ for FJ10, and $90.2 \pm 1.5$ Ma for FJ11. Samples FJ09, FJ10 and FJ11 K-feldspars also exhibit identical flat age spectra with plateau dates of $89.5 \pm 1.4, \quad 86.0 \pm 0.8$, and $87.2 \pm$ $1.4 \mathrm{Ma}$, respectively.

Sample FJ15 comes from a small mafic dyke emplaced into the migmatitic gneiss at Kingmen Island. The hornblende separates from sample FJ15 yield a flat age spectrum with a plateau date of $97.1 \pm 1.6 \mathrm{Ma}$. Biotite separates from 
FJ16, a sample from the Hsahsin quarry on Kingmen Island, yields a well-developed plateau over $90 \%$ of ${ }^{39} \mathrm{Ar}$ released with an age of $89.9 \pm 1.5 \mathrm{Ma}$ (Fig. 4).

The ${ }^{40} \mathrm{Ar} /{ }^{39} \mathrm{Ar}$ analytical results for the migmatitic gneisses indicate that the middle part of the Metamorphic Belt becomes younger southward along the maritime of the Fujian Province. The plateau dates for hornblende change from 109.6 $\pm 2.6 \mathrm{Ma}$ (FJ05) to $97.1 \pm 1.6 \mathrm{Ma}$ (FJ15). Biotite and K-feldspar yield ${ }^{40} \mathrm{Ar} /{ }^{39} \mathrm{Ar}$ dates from $105.3 \pm$ $2.1 \mathrm{Ma}$ and $100.7 \pm 2.1 \mathrm{Ma}$ (FJ05) in the north to $90.2 \pm$ 1.5 and $87.2 \pm 1.4 \mathrm{Ma}(\mathrm{FJ} 11)$ in the south.

Two migmatitic gneisses, one two-mica bearing granite and one schist samples were analyzed in order to elucidate the exhumation history of the southern part of PingtanDonshan Metamorphic Belt.

Sample FJ17 is a migmatitic gneiss, overlain by garnetsillimanite schist from the Longhai region. The hornblende and biotite separates from sample FJ17 both display welldefined plateau spectra with ages of $91.6 \pm 1.9$ and $86.9 \pm$ $1.8 \mathrm{Ma}$, respectively.

Muscovite separates from sample FJ18, a mica schist from Dongshan Island, yields a flat spectrum with a plateau date of $91.9 \pm 2.3 \mathrm{Ma}$. Sample FJ19 is a migmatitic gneiss collected from Dongshan Island. Similar to the FJ18 muscovite, the FJ19 biotite displays a well-defined plateau with an age of $87.7 \pm 1.8 \mathrm{Ma}$. The apparent dates of the FJ19 Kfeldspar gradually increase during heating and the age spectrum shows a slight staircase shape (Fig. 4). However, most of the steps still define a meaningful plateau on the spectrum with an age of $83.7 \pm 1.7 \mathrm{Ma}$. Muscovite and biotite extracted from a two-mica granite (FJ20) yield ${ }^{40} \mathrm{Ar} /{ }^{39} \mathrm{Ar}$ plateau ages of $93.7 \pm 1.9,88.4 \pm 1.8 \mathrm{Ma}$, respectively.

\subsection{The Changle-Nanao shear zone}

In order to constrain the timing of the movement along the Changle-Nanao shear zone, three samples were collected and analyzed. Sample FJ12 is a mylonitic gneiss which was collected in the shear zone. The hornblende from the mylonitic gneiss exhibits a flat spectrum with a plateau date of $102.8 \pm 2.2 \mathrm{Ma}$ for $95 \%$ of the total ${ }^{39} \mathrm{Ar}$ released, and $\mathrm{K}-$ feldspar separates yield an age of $88.0 \pm 1.8 \mathrm{Ma}$ (Table 1, Fig. 4). Biotite separated from the migmatitic gneiss (FJ13) surrounding this shear zone yields a well-developed plateau over $90 \%$ of ${ }^{39} \mathrm{Ar}$ released indicating an age of $101.8 \pm$ $2.3 \mathrm{Ma}$ (Fig. 4). K-feldspar from sample FJ13 displays a staircase-shaped spectra with apparent dates increasing monotonously with increasing temperatures, except for those with an anomalously old age at the lowest temperature step. These feldspars yield a meaningful plateau age of $87.0 \pm 1.8 \mathrm{Ma}$, which is similar to the age of feldspar separated from the mylonite (FJ12). Sample FJ14 is taken from a non-foliated mafic dyke, which is intrusive into samples FJ12 and FJ13. Other than at the highest-temperature step, the spectrum displays a relatively flat profile with an age of $82.2 \pm 1.7$ Ma over $90 \%$ of total ${ }^{39} \mathrm{Ar}$ released (Fig. 4).

\section{Discussion}

\subsection{Cooling history}

When the closure temperature is considered, geochronological data can be further applied to determine the cooling path (time-temperature path) for metamorphic rocks during exhumation. In the case of $\mathrm{K}-\mathrm{Ar}$ closure of the isotopic system during cooling is simply controlled by a diffusion mechanism. Thus, it is possible to estimate the closure temperatures for the $\mathrm{K}-\mathrm{Ar}$ isotope system in minerals if the related parameters such as activation energy, frequency factor, grain size and cooling rate are widely achieved (Dodson, 1973, 1986). On the basis of the obtained closure temperatures and the ${ }^{40} \mathrm{Ar} /{ }^{39} \mathrm{Ar}$ ages of the analyzed minerals, the time-temperature diagram for samples from the Metamorphic Belt can be derived as shown in Fig. 5.

The calculated thermal histories presented here record two periods of rapid cooling, the first at $132-110 \mathrm{Ma}$ and the second at 110-84 Ma. First, samples FJ01 and FJ02 from Pingtan Island, exhibit a period of modest to rapid cooling (rates of $10-50^{\circ} \mathrm{C} / \mathrm{m} . \mathrm{y}$.) from $132-110 \mathrm{Ma}$. As shown in Fig. 5, migmatitic gneisses collected from Pingtan Island appear to have cooled down at an average rate of $47^{\circ} \mathrm{C} / \mathrm{m}$.y. from $132-126 \mathrm{Ma}$ and then further declined to a rate of $13-20^{\circ} \mathrm{C} / \mathrm{m}$.y. until $\sim 110$ Ma during exhumation. The period of rapid cooling may reflect compressional unroofing of the Metamorphic Belt due to pre-132 Ma movement along the Changle-Nanao shear zone because it was simultaneous with deposition of the Tienhsiang Formation (155-120 Ma, Chen, 1989). The Tienhsiang Formation may have had a mélange origin as a result of the subduction of Kula/Izanagi plate beneath the Asiatic continent (Wang Lee and Wang, 1987; Hsu, 1988). The absolute age of incipient movement of the Fault is poorly known because of superimposed voluminous volcanic rocks around this area. However, the geochronological studies on the rocks from the northern part of the Metamorphic Belt reveal that the present surface rocks had already outcropped at $\sim 110 \mathrm{Ma}$ and no conspicuous exhumation is to be expected since then in this area. This interpretation is compatible with field observations that these metamorphic rocks are depositionally overlain by $110 \mathrm{Ma}$ volcanic rocks (FJV01, FJV02).

The second period of rapid cooling was constrained by the samples collected from the middle and southern part of Metamorphic Belt. By comparison, hornblende, muscovite, biotite and $\mathrm{K}$-feldspar ${ }^{40} \mathrm{Ar} /{ }^{39} \mathrm{Ar}$ ages for metamorphic rocks in the middle and southern part of the Metamorphic Belt show a generally southward decrease (Table 1). Although the northern areas began to cool slightly earlier than the southern region as evidenced by the ${ }^{40} \mathrm{Ar} /{ }^{39} \mathrm{Ar}$ ages from identical minerals, the rate of cooling, as determined from coexisting minerals with differing Ar closure temperatures, was nearly constant throughout the Metamorphic Belt. They appear to have cooled down at an average rate of $40-50^{\circ} \mathrm{C} / \mathrm{m}$.y. at 


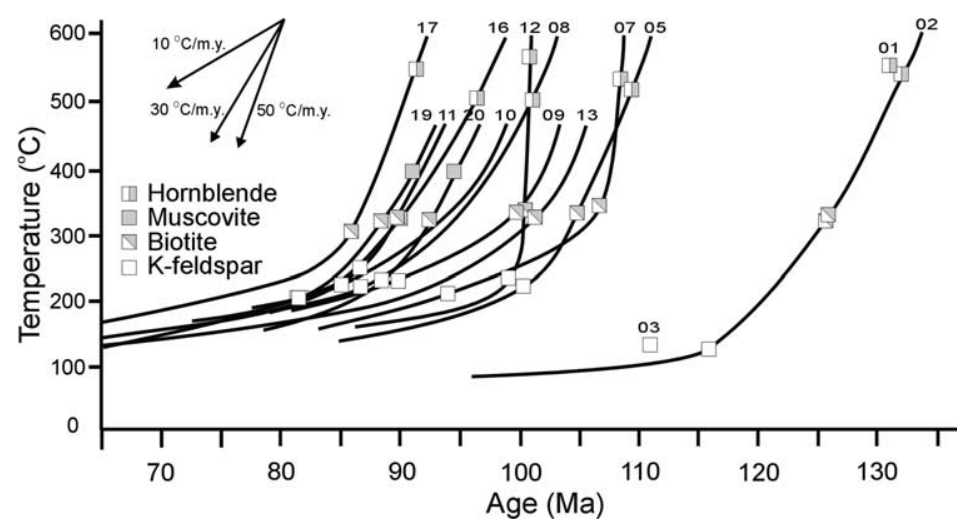

Fig. 5. Cooling history derived from thermochronological data for the Pingtan-Dongshan Metamorphic Belt.

$550-300^{\circ} \mathrm{C}$, followed by slower cooling of $\sim 15-30^{\circ} \mathrm{C} / \mathrm{m} . \mathrm{y}$. at $300-150^{\circ} \mathrm{C}$ (Fig. 5).

Movement along major faults potentially results in mylonitization and rapid uplift of the adjacent terrane. As mentioned earlier, FJ12 is a mylonized gneiss, collected from the Changle-Nanao shear zone, while FJ13 is a migmatitic gneiss occurring adjacent to the shear zone. Comparison of the quartz and feldspar textures with experimentally derived results for intracrystalline plastic flow suggests that the temperatures during mylonitic deformation were between 350 and $300^{\circ} \mathrm{C}$ (Huang et al., 1993; Wang et al., 1995). The hornblende dating result $(102.8 \pm 2.2 \mathrm{Ma})$ should suggest the time of closure for the isotopic system instead of mylonitization. The calculated thermal history presented here record an extremely high cooling rate of $\sim 173^{\circ} \mathrm{C} / \mathrm{m}$.y. from 102 to $101 \mathrm{Ma}$, followed by a cooling curve similar to other parts of the Metamorphic Belt indicating a relatively low rate of $\sim 12^{\circ} \mathrm{C} / \mathrm{m}$.y. during the Late Cretaceous (Fig. 5). Although mechanisms such as fluid convection or lateral heat flow can cause crustal rocks to cool, the lack of evidence for pervasive hydrothermal alteration suggests that the rapid cooling rate largely reflects tectonic denudation resulting from motion along ChangleNanao shear zone. The temperature of mylonitic deformation has evidently lower than the closure temperature estimated for hornblende (Table 1). Thus, the fast cooling and rapid uplift ages of 102-101 Ma is the best estimate for the time of movement along the Changle-Nanao shear zone in the Shihtaoshan region.

$\mathrm{A} \mathrm{U}-\mathrm{Pb}$ age of $122 \mathrm{Ma}$ for a deformed granodiorite in the Dongshan shear zone (Tong and Tobisch, 1996) along the Changle-Nanao shear zone has been interpreted as the timing of mylonitization. If this was the case, then the age for the onset of movement along the Fault should not be later than $122 \mathrm{Ma}$. The mafic dyke (FJ14) that crosscuts the fault also provides an age constraint for faulting. Its age (82 Ma) sets the upper limit for movement along the Changle-Nanao shear zone. Therefore, any significant displacement along this zone is likely to have occurred prior to $82 \mathrm{Ma}$.

\subsection{Tectonic implication of the Pingtan-Dongshan Metamorphic Belt in the Cretaceous}

In the past, the Pingtan-Dongshan Metamorphic Belt had been considered by many geologists to be a Mesozoic subduction complex. The subduction tectonism not only resulted in uplift of the Belt but also led to calc-alkaline magmatism in SE China during the Mesozoic (Fujian, 1985; Charvet et al., 1994; Zou, 1995; Chen et al., 1996; Lapierre et al., 1997; Xu et al., 1999). However, based on the scattered outcrops of gabbro and amphibolite bodies in this belt, Hsu et al. (1990), Li (1993) and Lu et al. (1994) suggested that the Changle-Nanao shear zone represents a suture zone resulting from collision between the Dongnanya and Huanan blocks during the late Mesozoic. They considered the Pingtan-Dongshan Metamorphic Belt as the remnant of an ancient orogenic complex. In their collision model, these mafic-ultramafic rocks were interpreted as a dismembered ophiolite suit from a Late Paleozoic ocean the so-called Gunanhai oceanic crust. They concluded that the Metamorphic Belt may have originated through metamorphism of an ophiolitic mélange under $P-T$ conditions higher than those experienced by the phyllitic mélange near the Quanzhou serpentinite. However, these interpretations have not gained much support. Palaeontological data show that the depositional age of the metasediments in the Metamorphic Belt is early Paleozoic (Huang et al., 1988; Yu et al., 1988). REE and Nd-Sr isotopic studies on the gabbroic rocks indicate subduction-related signatures which originated along a magmatic-arc (Zou, 1995; Xu et al., 1999). Gabbroic rock from Quanzhou dated by $\mathrm{U}-\mathrm{Pb}$ yields an identical age of $106.5 \pm 0.2 \mathrm{Ma}$ (Li et al., 1995), showing that the Quanzhou gabbroic rock was coeval and probably co-genetic with the magmatic belt. Moreover, a detailed survey in the maritime of the Fujian Province failed to find a late Mesozoic fold-thrust belt and foreland basin accommodating vast amounts of orogenic sediments that is common in orogenic belts. It is difficult to interpret the Changle-Nanao shear zone as a late Mesozoic suture zone on the basis of geochemical data and field observations. 


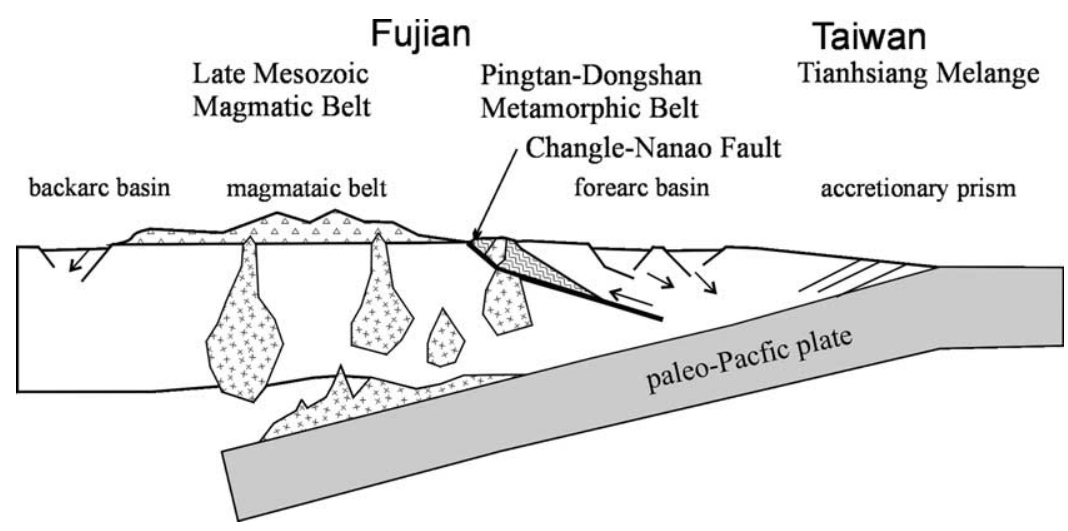

Fig. 6. The paleo-Pacific plate was subducted westward beneath the Eurasian continent during emplacement of the Yanshanian granite along with deposition of volcanic rocks in southeast China. The Tianhsiang Formation in Taiwan represents one of the subduction complexes along the western Pacific margin during the late Mesozoic. The Changle-Nanao shear zone is related to oblique subduction of the paleo-Pacific plate that formed a transcurrent fault at the rear of the forearc basin.

The Metamorphic Belt was juxtaposed against the early Cretaceous magmatic arc along the Changle-Nanao shear zone. In addition, the Magmatic Belt and the PingtanDongshan Metamorphic Belt represent a high temperature/low-pressure system in the Mesozoic arc (Uyeda and Miyashiro, 1974; Jahn et al., 1976, 1990; Fujian, 1985; Charvet et al., 1994; Chen et al., 1996; Lapierre et al., 1997). However, some authors (Lo et al., 1996; $\mathrm{Li}$, 2000) argued that this magmatic arc, more than $1000 \mathrm{~km}$ in width, was much larger than that (300$400 \mathrm{~km}$ ) normally observed in subduction zones. They interpreted the Cretaceous high-K calc-alkaline intrusive and volcanic rocks, as well as the coeval A-type granites and mafic rocks in SE China, as having formed in an extensional environment. It has also been proposed that SE China during the Mesozoic was similar to the presentday Basin and Range Province in the western US (Gilder et al., 1991). Recent studies have shown that calc-alkaline magmas may be generated in response to lithospheric extension (Davis and Hawkesworth, 1993; Hawkesworth et al., 1995). However, volcanic rocks with calc-alkaline affinities associated with the coeval 'tectonic mélange' are attributed to subduction.

In Taiwan, the appearance of high-pressure metamorphic minerals in metamorphosed ophiolitic blocks indicates that the Yuli Belt of the Tananao Basement Complex was subjected to high-pressure metamorphism. The occurrences and chemical compositions of these high-pressure mineral phases are similar to those in the Sambagawa and Franciscan high-pressure metamorphic belts (Yui and Lo, 1989). There was a general consensus that the high-pressure metamorphic event responsible for the formation of these highpressure rocks in Yuli occurred during the late Mesozoic Nanao Orogeny as a result of subduction of the Kula/Izanagi oceanic Plate beneath the Asian continent (Yen, 1963). The $100-110 \mathrm{Ma}{ }^{40} \mathrm{Ar} /{ }^{39} \mathrm{Ar}$ ages for omphacite and amphibole (Lo and Yui, 1996) from the Tananao Basement Complex of Taiwan indicate that a high-pressure metamorphic event occurred during the late Mesozoic. The date closely approximates the timing of magmatism (FJV01, FJV02), uplift of the Pingtan-Dongshan Metamorphic Belt and movement along the Changle-Nanao shear zone. Faunas from the Tienhsiang mélange (Chen, 1989) of the Tananao Basement Complex indicate that a subduction event occurred at around 155-120 Ma.

Pacific ocean spreading rates, as revealed by paleomagnetic anomaly lineations, were fastest during the late Jurassic-early Cretaceous (Nakanishi et al., 1992). This rapid spreading event seems to have occurred during a time when the subducted convergent-system around the Circum Pacific was active. It is suggested that the paleo-Pacific plate was subducted in a westerly direction beneath the Eurasian continent to form a magmatic belt along the margin (Nakajima et al., 1990). Part of the Yanshanian Magmatic Belt represents the inner belt of a magmatic arc, while the Tienhsiang Formation formed concordantly as an outer belt of subducted deposits (Fig. 6). The subduction episode in this area produced a broad magmatic belt possibly due to low-angle and oblique subduction of the paleo-Pacific plate. Oblique subduction could give rise to a metamorphic belt due to movement of the Changle-Nanao shear zone along the continental margin. Modern examples of oblique subduction zones, such as the Sunda arc, southwest Japan, northern New Zealand, and Kuril arc, show that strike-slip faults commonly developed on the overriding plate between the magmatic arc front and trench (Kimura et al., 1990). The Changle-Nanao shear zone may be related to oblique subduction of the paleo-Pacific plate that caused left-lateral reverse strike-slip movement at the rear of the forearc basin during the early Cretaceous.

\section{Conclusions}

In summary, our ${ }^{40} \mathrm{Ar} /{ }^{39} \mathrm{Ar}$ dating analyses on the metamorphic and volcanic rocks from the Pingtan-Dongshan 
Metamorphic Belt have provided some important results to reveal the uplift history of the Metamorphic Belt and movement of the Changle-Nanao shear zone. Based on the ${ }^{40} \mathrm{Ar} /{ }^{39} \mathrm{Ar}$ ages, it is shown that the Changle-Nanao shear zone was active from 132 to $82 \mathrm{Ma}$ and records two periods of rapid cooling, the first at $132-110 \mathrm{Ma}$ and the second at 110-84 Ma. The timing of exhumation spatially varied and appears to decline from north to south along the Metamorphic Belt. The close approximation of the timing of the deposition of the Tianhsiang mélange, the high-pressure metamorphic event and calc-alkaline magmatism would substantiate a subduction event occurring along the eastern margin of the Asian continent during the late Mesozoic. In light of S-C fabrics developed in the sheared volcanic rocks and the contemporaneous activities of movement of the Changle-Nanao shear zone and subduction event, the exhumation of the Pingtan-Dongshan Metamorphic Belt seems to have resulted from late Mesozoic compressional tectonics.

\section{Acknowledgements}

The present work was largely supported by the National Science Council (ROC), NSC85-2111-M-002-025. We thank Dr C.H. Lo for invaluable laboratory support. Deep appreciation goes to Mr K.L. Wu for his kind help in the field and to the staff of THOR Reactor at Tsing-Hua University for their help in irradiating the samples. Thanks also due to two reviewers for their constructive comments. The manuscript was improved by helpful comments from Dr Yuan Wang.

\section{References}

Charvet, J., Lapierre, H., Yu, Y., 1994. Geodynamic significance of the Mesozoic volcanism of southeastern China. J. Southeast Asian Earth Sci. 9 (4), 387-396.

Chen, C.H., 1989. Preliminary study of the fossil Dinoflagellates from the Tananao schist, Taiwan. Master thesis, National Taiwan University, 89p, (in Chinese with English abstract).

Chen, W.S., Yang, H.C., Lo, C.H., 1996. Tectonic evolution and uplifting history of the Pingtan-Dongshan metamorphic belt at the coast of Fujian Province. In: Annual Meeting of the Geological Society of China, pp. 534-538 (in Chinese)

Chen, C.H., Lin, Y., Lu, H.Y., Lee, C.Y., Tien, J.L., Lai, Y.H., 2000. Cretaceous fractionated I-type granitoids and metaluminous A-type granites in SE China: the Late Yanshanian post-orogenic magmatism. Trans. Royal Soc. Edinburgh: Earth Sciences 91, 195-205.

Cosca, M.A., O'Nions, R.K., 1994. A re-examination of the influence of composition on argon retentivity in metamorphic calcic amphiboles. Chem. Geol. 112, 39-56.

Davis, J., Hawkesworth, C.J., 1993. The petrogenesis of 30-20 Ma basic and intermediate volcanics from the Mogollon-Datil Volcanic Field, New Mexico, USA. Contrib. Mineral. Petrol. 115, 165-183.

Dodson, M.H., 1973. Closure temperature in cooling geochronological and petrological systems. Contrib. Mineral. Petrol. 40, 259-274.

Dodson, M.H., 1986. Closure profiles in cooling systems. Mater. Sci. Forum 7, 145-154.

Emerman, S.H., Marrett, R., 1990. Why dikes? Geology 18, 231-233.
Engebreton, D.C., Cox, A., Gordon, R.G., 1985. Relative motions between oceanic and continental plates. Geol. Soc. Am. Spec. Pap. 206, 59.

Faure, M., 1989. Pre-Eocene synmetamorphic structure in the MindoroRomblon -Palawan area, west Philippine, and implications for the history of Southeast Asia. Tectonics 8 (5), 963-979.

Filatova, N.I., 1996. Early and Middle Cretaceous evolution of active continental margins. Geotectonics 30 (2), 150-164.

Fujian (Bureau of Geology and Mineral Resources of Fujian Province), 1985. Regional Geology of Fujian Province. Geological Publishing House (in Chinese with English Abstract).

Gao, T., Huang, H., Lin, Z., 1991. Two significant terrane boundaries in southeastern coast of China. Geol. Fujian 10, 1-10.

Gilder, S.A., Keller, G.R., Luo, M., Goodell, P.C., 1991. Timing and spatial distribution of rifting in China. Tectonophysics 197, 225-243.

Hawkesworth, C., Turner, S., Gallagher, K., Hunter, A., Bradshaw, T., Rogers, N., 1995. Calc-alkaline magmatism, lithospheric thinning and extension in the Basin and Range. J. Geophys. Res. 100, 10,27110,286 .

Hsu, K.J., 1988. Melange and the melange tectonics of Taiwan. Proc. Geol. Soc. China 31 (2), 87-92.

Hsu, K.J., Li, J., Chen, H., Wang, Q., Sun, S., Sengor, A.M.C., 1990. Tectonic of South China: key to understanding West Pacific geology. Tectonophysics 183, 9-39.

Huang, H., Yang, C., Li, R., 1988. The plant remains of the Paleozoic from the metamorphic rocks of Dongshan. Geol. Fujian 7, 290.

Huang, H., Gao, K., Yang, C., Li, R., 1993. Study on the basic characteristics of the Changle-Nanao shear zoneed belt and Pingtan-Dongshan folded belt in Fujian Province. Geol. Fujian 12, 48-67.

Jahn, B.M., Chen, P.Y., Yen, T.P., 1976. Sb-Sr ages of granitic rocks in southeastern China and their tectonic significance. Geol. Soc. Am. Bull. $86,763-776$

Jahn, B.M., Zhou, X.H., Li, J.L., 1990. Formation and tectonic evolution of Southeastern China and Taiwan: isotopic and geochemical constraints. Tectonophysics $183,145-160$.

Lapierre, H., Jahn, B.M., Charvet, J., Yu, Y., 1997. Mesozoic felsic arc magmatism and continental olivine tholeiites in Zhejiang Province and their relationship with the tectonic activity in southeastern China. Tectonophysics 274, 321-338.

Lee, C.Y., 1994. Chronology and Geochemistry of basaltic rocks from Penhu Islands and mafic dikes from east Fujian: implications for the mantle evolution of SE China since the late Mesozoic. PhD thesis, Inst. Geol., Nat'1. Taiwan University, 233p.

Li, J., 1993. Tectonic framework and evolution of southeastern China. J. Southeast Asian Earth Sci. 8 (1-4), 219-223.

Li, H., Dong, T., Xiu, S., Zhou, X., 1995. Single zircon U-Pb chronological study on the gabbro from Quanzhou. Chin. Sci. Bull. 40, 158-160.

Li, X., 2000. Cretaceous magmatism and lithospheric extenxion in Southeast China. J. Asian Earth Sci. 18, 293-305.

Lo, C.H., Lee, C.Y., 1994. ${ }^{40} \mathrm{Ar} /{ }^{39} \mathrm{Ar}$ method of $\mathrm{K}-\mathrm{Ar}$ age determination of geological samples using Tsing-Hua Open Pool (THOR) Reactor. J. Geol. Soc. China 37, 1-22.

Lo, C.H., Yui, T.F., 1996. ${ }^{40} \mathrm{Ar} /{ }^{39} \mathrm{Ar}$ dating of the high-pressure rocks in the Tananao Basement Complex. Taiwan 39, 13-30.

Lo, C.H., Onstott, T.C., Wang Lee, C., 1993. ${ }^{40} \mathrm{Ar} /{ }^{39} \mathrm{Ar}$ dating of plutonic/ metamorphic rocks form Chinmen Island off southeast China and its tectonic implication. J. Geol. Soc. China 36, 35-55.

Lo, C.H., Chen, C.H., Yang, H.C., Lin, L.H., Liu, Y.S., Wang, P.L., 1996. Exhumation of metamorphic complexes in East China - a consequence of late Mesozoic extension tectonics. In: International Symposium On Lithosphere Dynamics of East Asia, Program and Extended Abstract, 76-78.

Lovera, O.M., Richter, F.M., Harrison, T.M., 1989. The ${ }^{40} \mathrm{Ar} /{ }^{39} \mathrm{Ar}$ thermochronometry for slowly cooled samples having a distribution of diffusion domain sizes. J. Geophys. Res. 94, 17,917-17,935.

Lu, H., Jia, D., Wang, Z., Gao, L., Shi, Y., Zhang, Q., 1994. Tectonic evolution of the Dongshan terrane, Fujian Province, China. J. Southeast Earth Sci. 7 (3-4), 349-365 
Kimura, G.K., Takahashi, M.S., Kono, M.S., 1990. Mesozoic collisionextrusion tectonic in eastern Asia. Tectonophysics 181, 15-23.

Martin, H., Bonin, B., Capdevila, R., Jahn, B.M., Lameyre, J., Wang, Y., 1994. The Kuiqi peralkaline granitic complex (SE China): petrology and geochemistry. J. Petrol. 35, 983-1015.

McDougall, I., Harrison, T.M., 1988. Geochronology and Thermochronology by the ${ }^{40} \mathrm{Ar} /{ }^{39} \mathrm{Ar}$ Method. Oxford University Press, New York $212 \mathrm{pp}$.

Nakajima, T., Shirohase, T., Shibata, K., 1990. Along-arc lateral variation of $\mathrm{Rb}-\mathrm{Sr}$ and $\mathrm{K}-\mathrm{Ar}$ ages of Cretaceous granitic rocks in Southwest Japan. Contrib. Mineral. Petrol. 104, 381-389.

Nakanishi, M.S., Tamaki, K.S., Kobayashi, K.Z., 1992. Magnetic anomaly lineations from Late Jurassic to Early Cretaceous in the west-central Pacific Ocean. Geophysics 109, 701-719.

35 collaborators, Odin, G.S., 1982. Interlaboratory standards for dating purposes. In: Odin, G.S. (Ed.). Numerical Dating in Stratigraphy. Wiley, Chichester, pp. 123-149.

Samson, S.D., Alexander Jr., E.C., 1987. Calibration of the interlaboratory ${ }^{40} \mathrm{Ar}-{ }^{39} \mathrm{Ar}$ dating standard, MMhb-1. Chem. Geol. (Isot. Geosci. Sect.) $66,27-34$.

Suppe, J., 1985. Principles of Structural Geology. Prentice-Hall, New Jersey.

Tong, W., Tobisch, O.T., 1996. Deformation of granitoid plutons in the Dongshan area, southeast China: constraints on the physical conditions and timing of movement along the Changle-Nanao shear zone. Tectonophysics 267, 303-316.

Uyeda, S., Miyashiro, A., 1974. Plate tectonics and the Japanese islands: a synthesis. Geol. Soc. Am. Bull. 85, 1159-1170.
Wang Lee, C.M., Wang, Y., 1987. Tananao terrane of Taiwan - its relation to the Late Mesozoic collision and accretion of the southeast China margin. Acta Geol. Taiwanica 25, 225-242.

Wang, X., Chen, W.S., Yang, H.C., Huang, H., 1995. Tectonics and evolution of the Fujian Coast Changle-Nanao metamorphism zone: preliminary study. Chin. J. Oceanol. Limnol. 13, 101-106.

Xu, X., Dong, C., Li, W., Zhou, X., 1999. Late Mesozoic intrusive complexes in the coastal area of Fujian, SE China: the significance of the gabbro-diorite-granite association. Lithos 46, 299-325.

Yang, H.C., Chen, W.S., Lo, C.H., Chen, C.H., Huang, H., Wang, X., Wang Lee, C.M., 1997. ${ }^{40} \mathrm{Ar} /{ }^{39} \mathrm{Ar}$ thermochronology of granitoids from the Pingtan-Dongshan metamorphic belt and its tectonic implication. J. Geol. Soc. China 40 (3), 559-585.

Yen, T., 1963. The metamorphic belts within the Tananao Schist terrain of Taiwan. Proc. Geol. Soc. China 6, 72-74.

Yu, W., Zhang, X., Shi, M., 1988. The discovery of microfossils in metamorphic rocks of Aojiau-Donggu of Dongshan, Fujian. Geol. Fujian 7, 290.

Yui, T.F., Lo, C.H., 1989. High-pressure metamorphosed ophiolitic rocks from the Wanjung area, Taiwan. Proc. Geol. Soc. China 32, 47-62.

Zhou, S.R., Wu, K.L., 1994. Zhangzhou I- and A-type granitic complex. Beijing: Science Press (in Chinese with English abstract).

Zou, H., 1995. A mafic-ultramafic rock belt in the Fujian coastal area, southeastern China: a geochemical study. J. Southeast Asian Earth Sci. $12(1 / 2), 121-127$. 